\title{
AN ANALYSIS ON INTRINSIC ELEMENTS OF KUNGFU PANDA 3 MOVIE
}

\author{
Susanto \\ STKIP PGRI Trenggalek \\ santosu620@gmail.com
}

\begin{abstract}
The objectives of the research are, first to analyze kinds the intrinsic elements find on Kungfu Panda 3 movie. And second, to find out the moral values on Kungfu Panda 3 movie. The data were collected from the dialogues, performance and attitude by the characters on Kungfu Panda 3 movie. The result of this research shown there were six kinds of intrinsic elements on Kungfu Panda 3 movie. Namely character and characterization, theme, point of view, plot, setting, and moral value. The result of this research also shown that there were two kinds of moral values, namely values of being and values of giving.
\end{abstract}

Key Words: Intrinsic Elements, Literature, Movie

CPendidikan Bahasa Inggris FPISH IKIP BU Malang

\section{Introduction}

English is the important part of language in the world. Most of countries in the world use English language, including in Indonesia. Algeo (1976: 1) states "English has become the most widespread language in the world, used by more people for more purpose than any other language on Earth". So, people use language to communicate with other to express the idea, share the feeling, experience and knowledge. Algeo (1976) states "Language is a system of conversational vocal signs by means of which human beings communicate". Human beings, like animal, person, and anything that life in this world certainly have language to communicate using vocal conversational with them social group.

In mastering of English language learners, has theory about literature. Literature is learn to analyze some a literary work. Taylor (1981: 1) states "literature like other arts, is essentially an imaginative act, that is an act of the writer's imagination in selecting, ordering and interpreting lifeexperience". Anything that can be said about the nature of literature holds true for both oral and written with form, style and social function.
Klarer (2004: 9) states "The classification of literary works into different genres has been a major concern of literary theory, they are fiction, drama, poetry, and film". Movie is another name for film or motion picture. This word is mostly used in American English. Although movie is commonly used in spoken language, many people tend to use the word film in academic and formal writing (Hasa, 2016). In this case, movie or film includes in a literary genre. Also the movie can be analyze through the dialogue between the characters, the gestures from each characters, the story, and also the picture from the movie. Movie is simply short for motion pictures (Barsam and Monahan, 2010: 3).

In literary works, there is always a constructive elements. There are the extrinsic elements and the intrinsic elements. Both of the elements are often mention by the critic in examine and or talking a novel or another literary works Nurgiyantoro (2007). Both of the elements are very important in a literary works, especially the intrinsic elements. Nurgiyantoro (2007) state "Intrinsic elements (intrinsic) are elements that build literary work itself. This elements what causes the present literary works as works of literatures". 
Studying about literature, especially on intrinsic elements will be easier for us to know the points of intrinsic elements like character and characterization and etc. We can know it, on the statement, attitude or behavior by the character's performance. It can be one of way to study and analyze about intrinsic elements. There are many animation movies have been shown, not only in theater, television, but also youtube.

One of the popular animation movie is Kungfu Panda 3. Kungfu Panda 3 is a 2016 Box Office movie from AS with a genre about animation, adventure, and comedy. This movie tell about what should the teacher, student, and parents do in supporting the children to reach their dream. And every character has a different behavior and attitude, with the condition we know to respect and appreciate with others like in this movie. Kungfu Panda 3 is very inspiring and good movie. Besides them, this movie has many aspect to be analyzed. One of those aspects is dialogue on the movie. Then the performance and attitude by the chracters on the movie.

The researcher is focused on analyzing on kinds of the intrinsic elements are found on Kungfu Panda 3 movie and moral values are found on Kungfu Panda 3 movie. Meanwhile, the objectives of this research are to find out kinds on the intrinsic elements and find out the moral values on Kungfu Panda 3 Movie. With analyze intrinsic elements on the movie, the researcher hopes that the result of this research can give useful information and reference for the readers who studying about literature especially on intrinsic elements.

\section{Research Method}

In this research the researcher as key the instruments. Qualitative research has actual settings as the direct source of data and the researcher is the key instrument (Bodgan and Biklen, 2007:4). The first instrument the researcher as data collector and the second is an observer to get data or information will be used to draw a conclusion in research.

Specifically, presence of the researcher is very significant, start from processing, analyze until found the conclusion of research. Researcher found activity of subject in the process analysis movie. In this research, the researcher as data collector and also observer will collect and observe the intrinsic elements in Kungfu Panda 3 movie that used by the characters, attitude, movements, and also the dialogue. And the moral values in the story of the movie.

The first instrument, the researcher as data collector is to collect the data about the movements, dialogue that saying, attitude that do by the characters, and the story series from the movie. And the second, after the data is collected the researcher observe the intrinsic elements and the whole moral from the data make notes based on what the researcher found during collect the data.

Conducted through some steps that are the writer collects the raw data from various sources such as from books, articles, internet, and movie. Meanwhile, in this phase, the researcher gets the data are from the analysis of the intrinsic elements and moral values on the Kungfu Panda 3 movie. After that, the researcher chooses the data to look for key issues and the researcher is able to process the data. Furthermore, the researcher analyzes more detail about processed data.

Research design is a method used in analyzing and collects the data to solve the research problem. Research has purpose to discover answers to meaningful questions through the application of some scientific procedures. In this research the researcher uses qualitative research. 
Creswell (2009: 4) stated that "Qualitative research is the process of research involves emerging questions and procedures, data typically collected in the participant's setting for exploring and understanding the meaning individuals or groups ascribe to a social or human problem".

Besides that, Qualitative researcher seeks to understand a phenomenon by focusing on the total picture rather than breaking it down into variables. The goal is a holistic picture and depth of understanding rather than a numeric analysis of data. As the explanation, qualitative research used by the researcher because of the data that collected are words and may pictures not numerical data. In qualitative research, the researcher made accurate explanation to analyze and present what have been found.

Ary, et al (2010: 468) state that: Narrative research has its roots in different humanities disciplines and focuses on stories (spoken or written) told by individuals about their lives. The researcher emphasizes sequence and chronology and a collaborative restorying process. .... A narrative can be any text or discourse. Narrative research provides accounts of human experiences by collecting and analyzing stories about lives. The stories are accounts of events and actions chronologically connected. Narrative research evolved from diverse disciplines in the humanities, such as literature, art, and film, as well as from disciplines such as psychology and sociology.

From that statement, movie is one of types of narrative that is spoken and written material. And also the stories about lives are accounts of events and action chronologically connected. It is used to analyze the intrinsic element that performs by the characters and also the moral values from the movie.
In the research procedure, researcher explains the procedures which she will conduct. There are some stages that can be conducted by the researcher to explain this research. According to Ary et al (2010: 31), the researcher will do some procedures to conduct this research are selecting the problem, review the literature, design the study, collect the data, analyze the data, interpret the data, and report the findings. More explanation about procedures in conducting this research will be described below.

Selecting the problem is the first step to investigate. The problem should be consequential enough to warrant investigation. Also, the answer to the problem is not already available, but the means for finding answers are available. Qualitative researcher begins with a general topic of interest. The problem statement may ask the "why" or "how" of certain phenomena. In this phase, the researcher formulates the problem on the focus of the research to her research.

Review the literature to gain more understanding and insight into the problem and to determine what research may already have been done. The researcher likely turn to the literature for help locating and formulating a researchable problem.

The researcher next plans how to conduct research to answer the question. The design is the researcher's plan for the study, which includes the method to be used, what data will be gathered, where, how, and from whom. In qualitative research, the design is flexible and may change during the investigation if appropriate. The design of qualitative research is thus often described as emergent.

The next step involves executing the research plan. Qualitative researcher also has a toolbox of data-gathering techniques, including in depth interviewing, participant observation, and document analysis. 
The data collected in research must be analyzed. Qualitative data generally take the form of words (descriptions, observations, impressions, recordings, and the like). The researcher must organize and so that can be described and interpreted. In this phase, the research organized and categorized the finding used the table. For example, to analyze character and characterization as follow:

The researcher next tries to interpret the findings in terms of the research problem. Qualitative researcher present their interpretations and explanations in narrative form. They do not talk about probability but try to emphasize the trustworthiness and credibility of the findings.

The last step in conducting the research is reporting results. Researcher must make their procedures, findings, and conclusions available in a form intelligible to others who may be interested.

The procedures in conducting the research according to Ary, et al (2010: 33) can be drawn in the following figure.

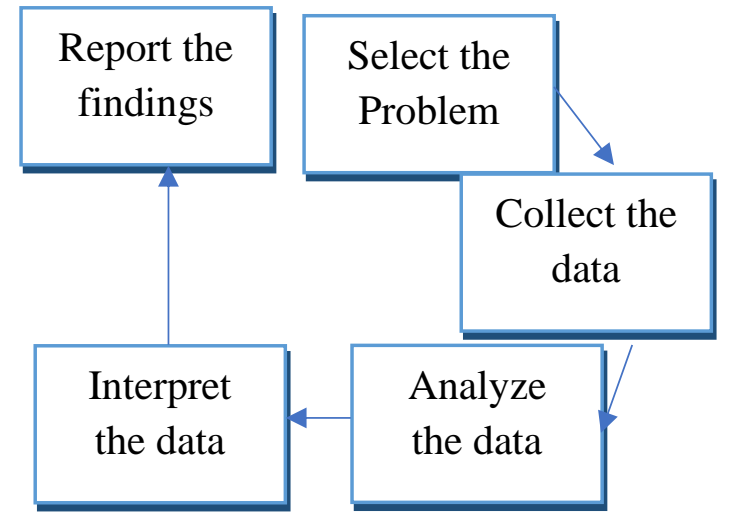

Figure 1. Stages in the Research Process

In conducting the research, the researcher should have data and source of data. To make this research the source of data taken from Kungfu Panda 3 movie. And, to get the data is from analysis intrinsic elements and the moral values from Kungfu Panda 3 movie. They are deriving from observing the dialogue, gesture, attitude by the characters, and the series of the story in Kungfu Panda 3 movie.

The section on technique of data collection describes the technique used to gather the data and explains why these techniques were chosen. And to get the data, the researcher has a technique to collect the data. Data is the important thing in this research, because the data is one of the requirements to do this research. The method that used by the researcher is observation use field notes method.

The most common method of recording the data collected during observation is field notes. The researcher may take brief notes during the observation but then later expands his or her account of the observation as field notes they contain what the researcher has seen and heard (Ary, et al 2002: 431).

Field notes have two components, they are:

First, the descriptive part is wwhich includes a complete description of the setting, the people and their reactions and interpersonal relationships, and accounts of events (who, when, what was done). Second, the reflective part is which includes the observer's personal feelings or impressions about the events, comments on the research method, decisions and problems, records of ethical issues, and speculations about data analysis.

The researcher's field notes present the data that will later be analyzed to provide an understanding of the research setting and the behavior of people within setting. It can be said that the successful outcome of the study relies on detailed, accurate, and extensive field notes.

In this method, there are two steps that the researcher uses: first, the researcher chooses the movie that will be to observe it is Kungfu Panda 3. And play the movie more than one times to 
understand about the movie. Second, make the field notes about intrinsic elements and the moral values from the movie as soon as possible following the observation, while the experience is still fresh in mind.

After collects the data, the researcher does data analysis. Based on Bogdan and Biklen (2007: 159) "By data analysis, mean the process of systematically searching and arranging the interview transcripts, fieldnotes, and other materials that accumulate to enable to come up with findings".

Miles and Huberman (1984) in Sugiyono (2014: 246) define analysis as consisting of three concurrent flows of activity: data reduction, data display, and conclusion drawing/verification. More explanation about procedures in data analysis will be described below.

Data reduction means summarizing, choose things that are basic, focusing on things that are important, look for themes and patterns. Thus the reduced data will provide a clearer picture, and facilitate researchers to conduct further data collection, and look for it when necessary. In this phase, the researcher watches the movie, analyze the dialogue between the characters, attitude, and then takes the implicit sentences that say by the character to make the moral value based on the kind of moral value.

After data reduction, then the next step is data display. In qualitative research, data display can be done in a brief description, draft, and correlation between categories, flowchart and others. Miles and Huberman (1984) state that "looking at displays help us to understand what is happening and to do something further analysis or caution on that understanding". In this research, the writer displays her data use narrative data.

After making data display, the researcher draws conclusion. The beginning conclusion is still tentative and it will be change if there is not valid and credible evidence.

In order to prove the validity and credibility of the conclusion, the researcher makes verification. In this phase the researcher chooses the theory which related with this research. So, that the data obtained reliable and automatically the result of analysis can answer the research focuses.

The procedures in technique analysis of the data can be drawn in the following figure.

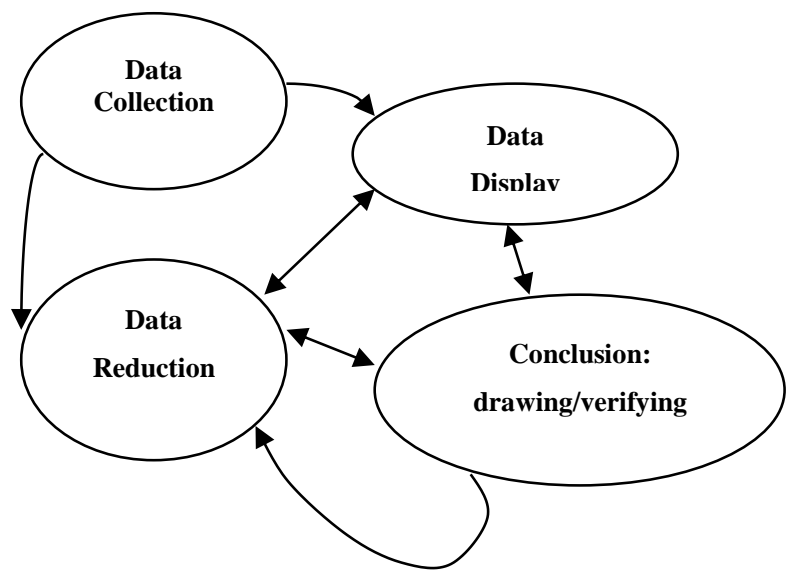

Figure 2. component in data analysis (interactive model)

In this part describes about the researcher's data valid or not. knowing the data valid or not. In this research, the researcher uses the theory of triangulation to establish the trustworthiness of the data.

Triangulation is qualitative crossvalidation. It assesses the sufficiency of the data according to the convergence of multiple data sources or multiple data collection procedures (adopted from William Wiersma, 1986 (in Sugiyono, 2011: 273). In triangulation there are three kinds of conduct the triangulation, they are: conduct the source triangulation, conduct the technique triangulation, and conduct the time triangulation.

From the kinds of conduct the triangulation above, the researcher 
conduct the triangulation of data through two ways. First, conduct the source triangulation, it mean the writer check the data from different sources. Second, conduct the time triangulation, the writer checks the data from different time (Sugiyono, 2014: 274).

\section{Result and Discussion Result}

After analyzing the data and classifying on the kinds of the intrinsic elements and moral values, the researcher intends to discuss the findings that have been investigated in this section to answer the research question. Based on the research finding, it is clear that the intrinsic elements and moral values of Kungfu Panda 3 movie show kinds of intrinsic elements and moral values.

Based on kinds of intrinsic elements, there are found:

Character and characterization on the movie are main character, peripheral character, protagonist character, and antagonist character. In every kinds there are the character on the movie that included in that kinds, they are:

1) Main character, in main character the researcher found three characters they are Po, Mr Ping, and Li Shan. Because, from the movie they performance from the beginning until last story in the movie and always existence in scene of the movie.

2) Peripheral character, in this kind the researcher found two characters they are Oogway and Mei Mei. It can know from the movie that they performance that exists once or some times in the story, and have relatively in short portion on the movie.

3) Protagonist character, in this kind the researcher found five characters they are Po, Oogway, Shifu, Li Shan, and The Five. Because, based on the movie know that the characters that was assumed to be a hero and with all the good things inside the characters make the viewer often identify themselves with this character and give sympathy and emphasizes and involve themselves in this character emotionally.

4) Antagonist character, based on the movie antagonist character is Kai. Based on the movie know that this character assumes as the bad person in the viewers opinion and causes conflict and become the rival for protagonist.

Plot, there are five indicates that included as a plot they are exposition, rising action, climax, conflict, and resolution.

Theme, in this movie there were two theme. First is the looking for identity, which still confused about his self and he was a dreamer that one time he would be what he dream. Second was the family, the family was important things. They support their son's dreams to become a dragon warrior.

Point of view, in this movie there are two kinds of point of view they are first person point of view and third person point of view.

Setting, there are three kinds that included as setting they are setting of place, setting of time, and setting of society.

1) Setting of place, the researcher found the places that used by the characters in this movie, they are Stairs, Rocks Near Sakura Tree, Noodle Shop, Valley, Dramatic Room, Garden Near The Oogway's Statue, Field, Bathing Tub, Jade Palace, Hall of Heroes, On The Roof Top, Store Room, Secret Village, Li Shan's Bedroom, and Spirit Realm.

2) Setting of time this movie take set of time in China, that there is a Panda become characteristic as Chinese. Another it, there is Chinese building and from this movie said as Jade Palace. And about the Kungfu is 
there important characteristic of Chinese, so the setting of time this movie takes in China when Kungfu is still closely to the habits of citizen in China.

3) Setting of society From this movie know how that this story talking about citizen in China on the last time. This movie take at the time the China society is still closely related to Kungfu, they believe that Chi is the greatest power by Chinese society. The habit of the citizens at the time is practicing Kungfu and that time the dumpling is still their favorite food.

Moral values, in moral values there are two kinds they are values of being and values of giving. In values of being found two kinds they are honesty and bravery. And in values of giving found two kinds they are Optimism and Kind and friendly.

\section{Discussion}

From the data analyzing above, the researcher found 6 kinds of 7 kinds intrinsic elements that mentioned by Mufidah (2011), those were:

- Character and Characterization

In character and characterization, by Nurgiyantoro's theory the researcher found two kinds of character and characterization which in those kinds of each had two kinds. First, based on character which existence in this movie were main character and peripheral character. In the main character the researcher found 3 characters that they were always existence on every scene from beginning until the end on movie. And about the peripheral character the researcher found 2 characters that they only have short portion on this movie. Second, based on appearance character there were protagonist and antagonist character and characterization. In the Protagonist character and characterization the researcher found 6 characters and characterization which in this kind the characters had the good thing inside. Then antagonist character and characterization the researcher found only 1 character, which the character was bad person and causes destroyed on this movie.

- Theme

Based on Martin and Hill's theory there was theme that contained on Kungfu Panda 3 movie, which theme was very important in literary works. Theme gave works meaning, it made relevant for the viewers. Because, theme is central idea or discussion in the movie that would extended the author through the whole of story. Theme couldn't find on the dialogues, performances, and attitudes of characters. But, it was from the whole of story on this movie.

- Plot

This kind of intrinsic elements was also found in this movie. based on Martin and Hill's theory in this movie there were five indicated that included as plot. They were: exposition, rising action, climax, conflict, and resolution. They were found on this movie story which influenced by the characters.

- Point of View

In this kind, in Nurgiyantoro's theory there were three points of view, they were: first person point of view, third person point of view, and mixed point of view. In the first person point of view, they were divided into two kinds, they were: the protagonist-narrator and the witness-narrator. And in the third person point of view, they were divided into two kinds, they were, omniscient and limited omniscient. But in this research the researcher focused on protagonistnarrator on first person point of view, and third person point of view. But, in this movie the dominant point of view used first person point of view that contained the dialogues by the protagonist characters. 
- Setting

There were some kind of setting based on Martin and Hill's theory, they were: setting of place, setting of time, and setting of society. In this research the researcher found all of kinds of the setting from dialogues, performances, and attitude by the characters.

- Moral Value

Based on Linda and Eyre's theory, there were two kinds of moral values, they were: values of being and values of giving. There were some kinds included as values of being, they were: honesty, bravery, love and peace, confident and potential, discipline, and purity and chastity. In this kind, the researcher found two kinds, there were honesty and bravery. There were some kinds included as values of giving, they were: loyalty and trustworthy, respect, love and affection, optimism, sensitive and unselfish, kind and friendly, and fair and generous. The researcher only two kinds there were optimism, kind and friendly.

\section{Conclusion}

This research was done to analyze the kinds of intrinsic elements and moral value that contained on Kungfu Panda 3 movie. This aim was to find intrinsic elements and moral value that contained on Kungfu Panda 3 movie. After having analyzed the data as stated in the previous chapter of this research the researcher made some conclusions based on the finding and the discussion. At the first, there are six kinds of intrinsic elements found o Kungfu Panda 3 movie, namely character and characterization, theme, plot, point of view, setting, and moral values. Second, moral values found on Kungfu Panda 3 movie there are two kinds, namely values of being (honesty and bravery) and values of giving (optimism and kind and friendly).

\section{References}

Algeo, John. 2010. The Origind And Development Of The English Language. Wadsworth: Cengage Learning.

Ary, D., Jacobs, L.C., Sorensen, C., \& Razavieh, A. 2002a. Introduction To Research In Education. Canada: Nelson Education.

Ary, D., Jacobs, L.C., Sorensen, C., \& Razavieh, A. 2010b. Introduction To Research In Education. Canada: Nelson Education.

Barsam, Richard. 2010. Looking At Movies. London: W.W Norton \& Company, Inc.

Bodgan, Robert C., Biklen, Sari Knopp. 2007. Qualitative Research For Education. United State of America: Pearson Education, Inc.

Creswell, John W. 2009. Research Design. United State of America: SAGE Publication, Inc.

Cynthia, Rahel. 2013. Intrinsic Elements of Literary Work. Online Journal. (online),

https://rahelcynthia.wordpress.co $\mathrm{m} / 2013 / 06 / 28 /$ intrinsic-elementsof-literary-work/. Accessed Juni $28^{\text {th }}, 2013$.

Della, Mia Vita. 2016. Kung Fu Panda 3 Jadi Film Animasi Terlaris di China. (online), http://m.muvila.com/film/artikel/ kung-fu-panda-3-jadi-filmanimasi-terlaris-di-china160229r.html. Accessed February $29^{\text {th }}, 2016$.

Efendi, Nurul. 2011. An Analysis Of The Main Character Of Evan Taylor In A Ugust Rush Movie. Unpublished Thesis. Salatiga: STAIN Salatiga.

Ezra, Reino. 2016. Kung Fu Panda 3 Taklukkan Box Office Amerika. (online), http://m.muvila.com/film/artikel/ kung-fu-panda-3-taklukkan-box- 
office-amerika-160202v.html.

Accessed February 02, 2016.

Hasa. 2016. Difference Between Film and Movie. Online Journal.

(online),

http://pediaa.com/difference-

between-film-and-movie/, accessed 24 Agustus 2016.

Klarer, Mario. 2004. An Introduction To

Literary Studies. English:

Routledge.

Martin, Alex., Hill, Robert. Anatomy of

A Novel. Prentice Hall.

Mufidah. 2011. Unsur IntrinsikEkstrinsik Sastra. 23 September 2011. 1.

Nurgiyantoro, Burhan. 2015. Teori

Pengkajian Fiksi. Yogyakarta:

Gadjah Mada University Pres.

Sugiyono. 2014. Metode Peneitian

Kuantitatif, Kualitatif dan $R \& D$.

Bandung: Alfabeta.

Tim Dosen STKIP PGRI Tulungagung.

2017. Pedoman Penulisan Karya

Ilmiah. (5 $5^{\text {th }}$ d). Tulungagung:

UPPM STKIP PGRI

Tulungagung.

(online).

(http://www.pusatsinopsis.com/2

015/10/sinopsis-kung-fu-panda-

3-2016.html, downloaded on

February $\left.10^{\text {th }}, 2017\right)$.

(online).

http://www.muvila.com/film/rev

iew/movie-review-kung-fu-

panda-3-jati-diri-sejati-po-

160319s.html, downloaded on

March $4^{\text {th }}, 2017$ ). 